\title{
RELASI PEMIMPIN DENGAN RAKYAT DALAM PERSPEKTIF AL-QUR'AN
}

\author{
Asrori Mukhtarom \\ asrorimukhtarom84@gmail.com \\ (Dosen Fakultas Agama Islam, Universitas Muhammadiyah Tangerang)
}

\begin{abstract}
Abstrak;
Al-Qur'an menggambarkan relasi pemimpin dengan rakyat dengan harmonis dan seimbang diantara keduanya, misalnya ayat yang mengisyaratkan kewajiban pemimpin untuk menegakkan keadilan di tengah masyarakat (QS. An-Nisa [4] : 58), melindungi hak asasi rakyat (QS. Al-An'am [6]: 151-152), dan menjaga keutuhan negara dari segala bentuk penjajahan dan penindasan (QS. Al-Anfal [8]: 60). Al-Qur'an juga mengisyaratkan kewajiban rakyat menaati pemimpinnya (QS. An-Nisa [5]: 59), membela negara (QS. Ali Imran [3]: 92), dan berperan serta dalam melaksanakan kebajikan (QS. Al-Maidah [5]: 2). Metode penelitian dalam tulisan ini menggunakan metode maudhû' $i$, yaitu metode menghimpun seluruh ayat al-Qur'an yang memiliki tujuan dan tema yang sama. Kemudian menguraikannya dengan menjelajahi seluruh aspek yang dapat digali dengan merujuk pendapat para ahli tafsir.
\end{abstract}

\section{Kata kunci: Pemimpin, Rakyat, Al-Qur'an.}

\section{A. Pendahuluan}

Relasi pemimpin dengan rakyat lahir dari kontrak sosial. Di Barat, teori kontrak sosial (perjanjian masyarakat) menjadi sebuah teori yang sangat mempengaruhi alam pemikiran Barat pada abad pertengahan hingga zaman Renaissance, bahkan sampai abad ke 18 di antara pemikir Barat yang sangat berpengaruh dalam teori tersebut adalah Thomas Hobbes (1588-1676), John Locke (16321704), dan Jean Jacques Rousseau (17121778). Teori tersebut didasarkan atas pemahaman bahwa kehidupan manusia dipisahkan pada dua zaman, yaitu zaman sebelum bernegara dan zaman setelah bernegara (status naturalis, state of nature). Dalam teori ini dijelaskan bahwa pada awal mulanya manusia itu hidup dalam keadaan sosial yang kacau tanpa hukum dan tanpa pemerintahan. Keadaan itu tidak dapat dibiarkan berlangsung terus, manusia dengan akalnya mengerti dan menyadari bahwa demi kelanjutan hidup mereka sendiri maka keadaan kacau tersebut harus diakhiri. Lalu mereka mengadakan perjanjian untuk hidup bersama dengan menyepakati salah seorang diantara mereka untuk menjadi pemimpin bagi mereka. Dengan perjanjian itu, maka timbulah sebuah negara. ${ }^{1}$ Teori kontrak sosial berasumsi bahwa negara dan warga negara memiliki relasi dan kewajiban timbal balik secara berimbang. Negara yang dipimpin oleh kepala negara mempunyai kewajiban membimbing rakyat dan mengelola negara dengan sebaikbaiknya, karena rakyat telah memberikan sebagian hak dan kebebasannya serta berjanji setia kepada mereka yang mengurus rakyat. Teori ini menjadi cikal bakal bagi dasar undang-undang tertulis yang mengatur batas-batas hak dan

${ }^{1}$ Dede Rosyada, dkk, Pendidikan Kewargaan (Civic Education): Demokrasi, Hak Asasi Manusia dan Masyarakat Madani, Jakarta: Kencana, 2007, hlm. 47-52. 
kewajiban kedua belah pihak secara $^{2}$

Dalam kajian pemikiran politik Islam teori kontrak sosial disebut bai'at. Bai'at telah diterapkan oleh para wakil dari penduduk Yatsrib yang mengangkat Muhammad sebagai pemimpin mereka. Konsep bai'at itu dengan sistem dan cara yang berbeda-beda. Kemudian diterapkan pula dalam proses pengangkatan Khulafaur Rasyidin, para pemimpin dinasti Bani Umayah, dinasti Bani Abbas, dan dinasti Utsmani hingga berakhirnya sistem khilafah secara keseluruhan di dunia Islam pada tahun1924. ${ }^{3}$ Allah SWT menurunkan al-Qur'an sebagai petunjuk bagi manusia. Dalam petunjuk tersebut terdapat seperangkat aturan dan nilai yang mengatur urusan kehidupan manusia. Dalam hal ini Allah menegaskan bahwa tidak ada satu pun yang tidak dibicarakan di dalam al-Quran. Allah berfirman:

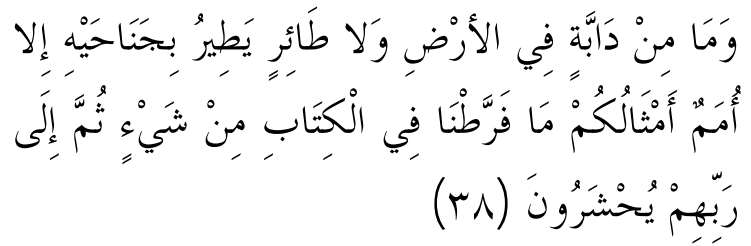

Dan tiadalah binatang-binatang yang ada di bumi dan burung-burung yang terbang dengan kedua sayapnya, melainkan umat (juga) seperti kamu. Tiadalah Kami alpakan sesuatupun dalam al-Kitab,

\footnotetext{
${ }^{2}$ Para ahli mengemukakan teori pembentukan negara dibedakan menjadi dua, yaitu teori klasik dan teori modern. Yang termasuk teori klasik yaitu teori hukum alam, teori kontrak sosial, dan teori ketuhanan. Sedangkan yang termasuk teori modern yaitu penaklukan, peleburan, pemisahan, pendudukan, dan pembentukan. Aryaning Arya Kresna, Etika dan Tata Tertib Hidup Berwarga Negara (Sebagai Mata Kuliah di Perguruan Tinggi), Jakarta: Penerbit Salemba Humanika, 2010, Hlm. 94.

${ }^{3}$ Shobahussurur, "Islam dan Kekuasaan (Studi Analitik Tentang Kritik Ibn Taimiyah Terhadap Sistem Kekuasaan)". Disertasi. PPs UIN Syarif Hidayatullah Jakarta, 2005, Hlm. 202.
}

kemudian kepada Tuhanlah mereka dihimpunkan. (QS. Al-An'am [6]: 38)

Ayat di atas mempertegas bahwa alQur'an merupakan kitab suci yang membahas segala aspek kehidupan manusia baik secara pribadi maupun kelompok, dan karena itu ditemukan petunjuk-petunjuk tata cara hidup bermasyarakat, berbangsa, bernegara, serta hubungan antara pemimpin dan rakyat.

Tulisan ini mengungkap relasi pemimpin dengan rakyat menurut alQur'an. Dari sekian ribu ayat-ayat alQur'an, di dalamnya terdapat prinsipprinsip terkait relasi pemimpin dengan rakyat, misalnya ayat yang mengisyaratkan kewajiban pemimpin bertindak adil (QS. An-Nisa [4]: 58), hak bagi rakyat (QS. AlIsra [17]: 33), menjaga persatuan dan persaudaraan (QS. Al-Hujurat [49]: 13), dan lain sebagainya.

\section{B. Relasi Pemimpin dengan Rakyat dalam Perspektif Al-Qur'an}

Al-Qur'an yang di dalamnya terdapat seperangkat nilai-nilai telah memberikan petunjuk terkait relasi pemimpin dan rakyat. Relasi tersebut dapat dilihat dari kewajiban pemimpin dan hak rakyat yang diisyaratkan dalam al-Qur'an. Menurut Imam Mawardi, tugas pemimpin itu mengambil alih peran kenabian dalam menjaga agama dan mengatur dunia. Hukum mengangkat pemimpin yang memiliki kemampuan menjalankan tugas di atas pada umat adalah wajib. ${ }^{4}$

$$
\text { Al-Qur'an mengisyaratkan }
$$

kewajiban pemimpin di berbagai surat dan ayat, isyarat-isyarat tersebut kemudian dikomentari oleh para tafsir. Berikut pejelasannya:

\footnotetext{
${ }^{4} \mathrm{Abu}$ al-Hasan Ali Ibn Muhammad Ibn Habib al-Mawardi, Al-Ahkam As-Sulthaniyyah: Hukum-Hukum Penyelenggaraan Negara dalam Syari'at Islam, diterjemahkan oleh Fadli Bahri dari judul Al-Ahkam Al-Sulthaniyyah fi Al-Wilayah AdDiniyyah, Bekasi: Darul Falah, 2013, Hlm. 23-24.
} 


\section{Pemimpin Wajib Menegakkan Keadilan}

Keadilan merupakan salah satu dari sekian banyak prinsip-prinsip ajaran Islam yang harus ditegakkan, termasuk dalam urusan bernegara. Kewajiban menegakkan keadilan sebagaimana dijelaskan dalam alQur'an:

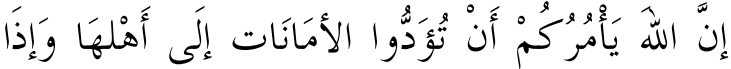

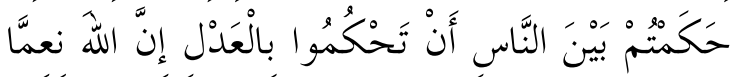

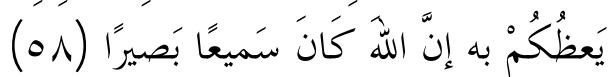

Sesungguhnya Allah menyuruh kamu menyampaikan amanat kepada yang berhak menerimanya, dan (menyuruh kamu) apabila menetapkan hukum di antara manusia supaya kamu menetapkan dengan adil. Sesungguhnya Allah memberi pengajaran yang sebaik-baiknya kepadamu. Sesungguhnya Allah adalah Maha Mendengar lagi Maha Melihat. (QS. An-Nisa [4]: 58)

Menurut Sayyid Quthb, ayat di atas merupakan tugas kaum muslimin sekaligus akhlak mereka, termasuk para pemimpin, yaitu menunaikan amanat-amanat kepada yang berhak menerimanya. Adapun dalam perintah agar memutuskan hukum dengan adil di antara manusia, maka nash ini bersifat mutlak yang berarti meliputi keadilan yang menyeluruh di antara manusia, bukan keadilan di antara sesama muslim saja atau golongan yang lainnya, karena keadilan merupakan hak setiap manusia hanya karena dia diidentifikasi sebagai manusia. Maka, identitas sebagai manusia inilah yang menjadikannya berhak terhadap keadilan itu. Umat Islam harus menegakkan keadilan ini dalam memutuskan hukum di antara manusia, mukmin, ataupun kafir, teman ataupun lawan, orang berkulit putih atau berkulit hitam, orang Arab ataupun orang non Arab. $^{5}$ Dalam ayat lain Allah juga berfirman:

${ }^{5}$ Sayyid Quthb, Tafsir Fi Zhilalil Qur'an, Jakarta: Gema Insani Press, 2002, Hlm. 397

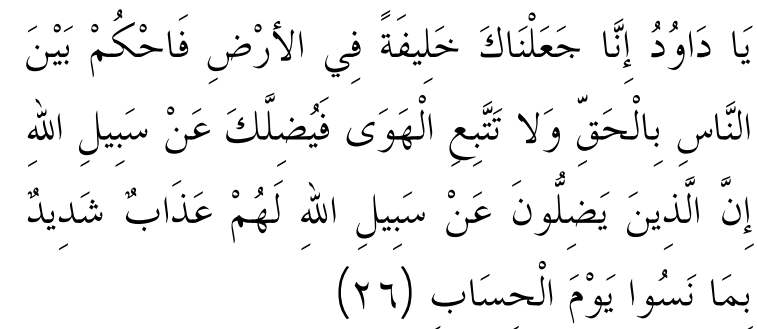

Hai Daud, sesungguhnya Kami menjadikan kamu khalifah (penguasa) di muka bumi, maka berilah keputusan (perkara) di antara manusia dengan adil dan janganlah kamu mengikuti hawa nafsu, karena ia akan menyesatkan kamu dari jalan Allah. Sesungguhnya orangorang yang sesat dari jalan Allah akan mendapat azab yang berat, karena mereka melupakan hari perhitungan. (QS. AsShaad [38]: 26)

Menurut Ibnu Katsir, ayat di atas merupakan wasiat Allah kepada semua pemegang kekuasaan agar menerapkan sistem hukum yang berkeadilan yang bersumber dari-Nya, dan tidak melakukan penyimpangan. Pada ayat ini juga disebutkan bahwa konsekuensi tidak adil atau penyimpangan hukum sangatlah fatal, yaitu siksa yang amat pedih. ${ }^{6}$ Oleh karenanya setiap pemimpin atau penguasa harus memiliki komitmen terhadap keadilan agar terwujudnya negara yang damai dan sejahtera.

Dalam rangka menerapkan sistem keadilan, seorang pemimpin atau kepala negara harus tegas dalam memberikan sanksi kepada para hakim-hakim dan para penegak hukum yang menciderai rasa keadilan bagi masyarakat, terutama masyarakat bawah. Jangan sampai hukum tajam ke bawah dan tumpul ke atas, artinya penegakkan hukum yang tembang pilih dan diskriminatif. Dalam prakteknya, Rasulullah selalu mengutus para hakim ke

${ }^{6}$ Ibnu Katsir, Tafsir Ibnu Katsir, diterjemahkan oleh M. Abdul Ghoffar E.M dari judul Lubâbu at-Tafsîr Ibnu Katsîr, Jakarta: Pustaka Imam Syafi'i, 2004, Hlm. 62. 
daerah-daerah untuk menetapkan hukum dengan seadil-adilnya, karena keadilan itu lebih dekat kepada takwa. Sebagaimana firman Allah:

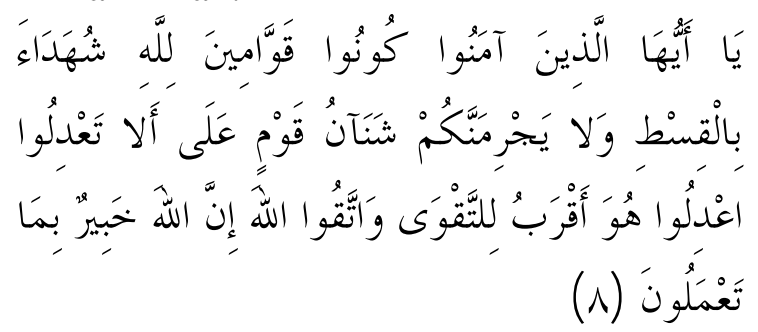

Hai orang-orang yang beriman hendaklah kamu jadi orang-orang yang selalu menegakkan (kebenaran) karena Allah, menjadi saksi dengan adil. Dan janganlah sekali-kali kebencianmu terhadap sesuatu kaum, mendorong kamu untuk berlaku tidak adil. Berlaku adillah, karena adil itu lebih dekat kepada takwa. Dan bertakwalah kepada Allah, sesungguhnya Allah Maha Mengetahui apa yang kamu kerjakan. (QS. Al-Maidah [5]: 8)

\section{Pemimpin Wajib Menjamin Hak Rakyatnya}

Kata "hak" memiliki beragam makna, antara lain: (1) benar; (2) milik; (3) kewenangan; (4) kekuasaan untuk berbuat sesuatu; (5) kekuasaan yang benar atas sesuatu atau menuntut sesuatu; (6) derajat atau martabat. ${ }^{7}$ Sedangkan kata asasi bermakna segala sesuatu yang bersifat dasar, prinsip dan fundamental. Jadi hak asasi merupakan hak-hak dasar manusia yang dimiliki bukan pemberian dari masyarakat atau negara melainkan berdasarkan martabatnya sebagai manusia. $^{8}$

Setiap negara atau pemimpin negara wajib menjaga hak asasi setiap warga

${ }^{7}$ Tim Penyusun Kamus Pusat Pembinaan dan Pengembangan Bahasa Depdikbud RI, Kamus Besar Bahasa Indonesia, Jakarta: Balai Pustaka, 1988, hlm. 292.

${ }^{8}$ Achmad, “ Konsep Hak-Hak Asasi Manusia Dalam Al-Qur'an”. Disertasi. PPs UIN Syarif Hidayatullah Jakarta, 2003, hlm. 34-35. negaranya. Hal tersebut sebagaimana dijelaskan dalam al-Qur'an yang selalu berkomitmen menjamin hak asasi manusia. Di antara ayat yang memerintahkan untuk menjaga hak asasi manusia adalah:

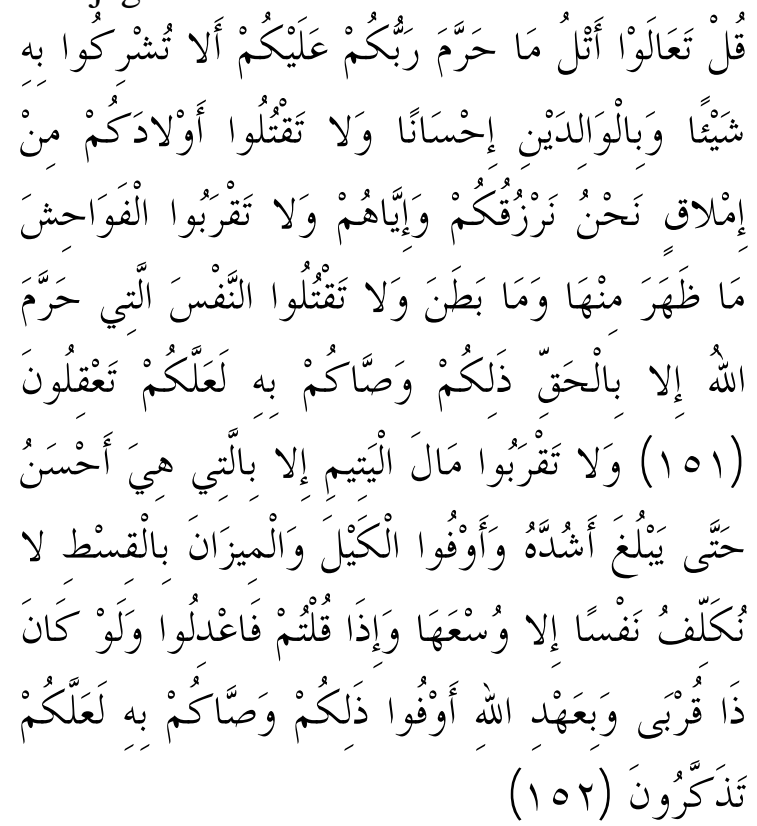

Katakanlah: "Marilah kubacakan apa yang diharamkan atas kamu oleh Tuhanmu yaitu: janganlah kamu mempersekutukan sesuatu dengan Dia, berbuat baiklah terhadap kedua orang ibu bapak, dan janganlah kamu membunuh anak-anak kamu karena takut kemiskinan, Kami akan memberi rezki kepadamu dan kepada mereka, dan janganlah kamu mendekati perbuatan-perbuatan yang keji, baik yang nampak di antaranya maupun yang tersembunyi, dan janganlah kamu membunuh jiwa yang diharamkan Allah (membunuhnya) melainkan dengan sesuatu (sebab) yang benar". Demikian itu yang diperintahkan kepadamu supaya kamu memahami(nya). Dan janganlah kamu dekati harta anak yatim, kecuali dengan cara yang lebih bermanfaat, hingga sampai ia dewasa. Dan sempurnakanlah takaran dan timbangan dengan adil. Kami tidak memikulkan beban kepada sesorang melainkan sekedar kesanggupannya. Dan apabila kamu berkata, maka hendaklah kamu berlaku adil, kendatipun ia adalah kerabat (mu), dan penuhilah janji Allah, 
yang demikian itu diperintahkan Allah kepadamu agar kamu ingat. (QS. AlAn'am [6]: 151-152).

Manurut Sayyid Quthb, ayat di atas merupakan ketetapan Ilahi yang di dalamnya mengandung yang di antaranya adalah apa yang diharamkan oleh Allah dengan pasti. Yang diharamkan Allah dalam redaksi dari dua ayat di atas di antaranya adalah melakukan pembunuhan atau pelanggaran terhadap hak hidup seseorang. ${ }^{9}$ Jika dianalisa lebih dalam, kedua ayat di atas dengan jelas memberikan jaminan terhadap hak asasi manusia, yaitu: (1) jaminan hak beragama tercermin dalam larangan menyekutukan Allah, "janganlah kamu mempersekutukan sesuatu dengan Dia". Redaksi ayat tersebut juga mengisyaratkan larangan memaksa orang untuk mempersekutukan Allah. (2) jaminan hak keamanan tercermin dalam ayat "Janganlah kamu mendekati perbuatan-perbuatan yang keji, baik yang nampak di antaranya maupun yang tersembunyi", ayat ini mengisyaratkan larangan untuk mengganggu keamanan dan kenyamanan seseorang. (3) jaminan hak hidup tercermin dalam ayat "Janganlah kamu membunuh jiwa yang diharamkan Allah (membunuhnya) melainkan dengan sesuatu (sebab) yang benar". (4) hak persamaan tercermin dalam ayat "Dan sempurnakanlah takaran dan timbangan dengan adil".

Perlindungan kepada warga negara merupakan kewajiban negara. Hal tersebut sebagaimana telah dicontohkan oleh Rasulullah ketika memimpin negara Madinah dengan membuat Piagam Madinah dalam pasal 15 yang isinya: "Sesungguhnya jaminan atau perlindungan Allah itu satu. Dia melindungi orang lemah di antara mereka, dan sesungguhnya orang-orang mukmin

\footnotetext{
${ }^{9}$ Sayyid Quthb, Tafsir Fi Zhilalil Qur'an, Jakarta: Gema Insani Press, 2002, Hlm. 244.
}

sebahagian mereka adalah penolong atau pembela terhadap sebagian bukan golongan lain". 10

Abul A'la al-Maududi menyatakan ada beberapa hak-hak warga yang harus dilindungi, yaitu keselamatan jiwa, kepemilikan, kehormatan, penjagaan kehidupan pribadi, hak untuk menolak kezaliman, kebebasan mengkritik, kebebasan berkumpul, kebebasan beragama, keamanan dari penindasan, ditanya tentang perbuatannya sendiri dan tidak ditanya tentang perbuatan-perbuatan orang lain atau ditahan karenanya: ${ }^{11}$ Pemimpin berkewajiban untuk memelihara keutuhan dan kedaulatan negara.

\section{Pemimpin Berkewajiban Untuk Menyejahterakan Rakyat}

Negara adalah suatu organisasi dalam suatu wilayah yang memiliki kekuasaan tertinggi yang sah dan ditaati oleh rakyatnya. Keberadaan negara, seperti organisasi secara umum, adalah untuk memudahkan anggotanya (rakyat) mencapai tujuan bersama atau citacitanya. Negara memiliki kekuasaan yang kuat terhadap rakyatnya. Kekuasaan, dalam arti kemampuan seseorang atau suatu kelompok untuk mempengaruhi orang lain atau kelompok lain, dalam ilmu politik biasanya dianggap bahwa memiliki tujuan demi kepentingan seluruh warganya. Dengan demikian, kekuasaan yang dimiliki oleh sekelompok orang yang berperan sebagai penyelenggara negara adalah semata-mata demi kesejahteraan warganya, negara merupakan aktor pertama dan untama dalam mencapai janji

${ }^{10}$ J. Suyuti Pulungan, Prinsip-Prinsip Pemerintahan Dalam Piagam Madinah Ditinjau Dari Pandangan Al-Qur'an, Jakarta: PT Raja Grafindo Persada, 1994, Hlm. 290.

${ }^{11}$ Abul A'la al-Maududi, Khilafah dan Kerajaan, diterjemahkan oleh M. Al-Baqir dari judul al-Khilafah wa al-Mulk, Bandung: Penerbit Karisma, 2007, Hlm.70-74. 
kesejahteraan kepada rakyat, terutama memainkan peran distribusi sosial.

Ajaran Islam sangat menjamin kesejahteraan warga. Hal tersebut sebagaimana banyak diisyaratkan di beberapa ayat al-Qur'an, di antaranya adalah dalam surat at-Taubah ayat 103:

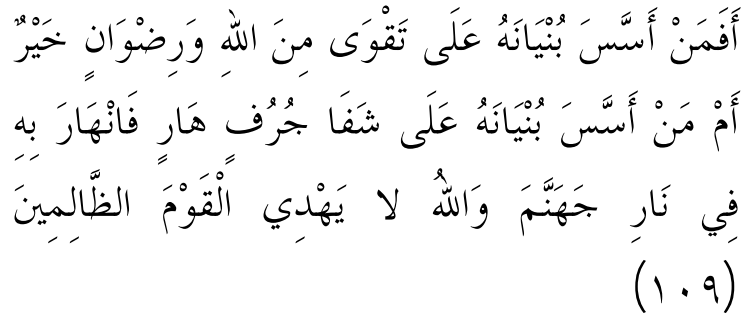

Ambillah zakat dari sebagian harta mereka, dengan zakat itu kamu membersihkan dan mensucikan mereka dan mendo'alah untuk mereka. Sesungguhnya do'a kamu itu (menjadi) ketenteraman jiwa bagi mereka. Dan Allah Maha Mendengar lagi Maha Mengetahui. (QS. At-Taubah [9]: 109).

Ibnu Katsir menjelaskan bahwa walaupun ayat di atas merupakan perintah Allah kepada Rasulullah untuk mengambil zakat dari muzakki, namun ia berlaku umum untuk semua pemimpin umat Islam. $^{12}$ Dalam pemerintahan Rasulullah, zakat diwajibkan dengan cara mengambil sebagian harta warga untuk didistribusikan kepada warga yang miskin. Al-Mawardi menetapkan bahwa di antara kewajiban negara adalah mengatur keluar masuk uang negara; berupa pengumpulan dan pendistribusian zakat dan pajak. Di Indonesia, hal ini juga diakomodasi oleh UUD 1945 yang menyebutkan bahwa salah satu kewajiban presiden adalah mengatur anggaran pendapatan dan belanja negara untuk kemakmuran rakyat. Dalam hal ini presiden mengajukan anggaran belanja yang kemudian dibahas oleh DPR dengan

${ }^{12}$ Ibnu Katsir, Tafsir Ibnu Katsir, diterjemahkan oleh M. Abdul Ghoffar E.M dari judul Lubâbu at-Tafsîr Ibnu Katsîr, Jakarta: Pustaka Imam Syafi' i, 2004, Hlm. 199. memperhatikan pertimbangan DPD. Dalam rangka merealisasikan kesejahteraan rakyat, presiden memiliki wewenang untuk menarik pajak atau pungutan lain yang bersifat memaksa. Tentu saja kesejahteraan yang dimaksud adalah kesejahteraan yang berlaku bagi seluruh rakyat, sebagaimana sila ke lima dari Pancasila "keadilan sosial bagi seluruh rakyat Indonesia" dan dalam alinea ke-4 Pembukaan Undang-Undang Dasar Negara Republik Indonesia Tahun 1945 dikatakan bahwa "Kemudian dari pada itu untuk membentuk suatu pemerintahan negara Indonesia yang melindungi segenap bangsa Indonesia dan seluruh tumpah darah Indonesia dan untuk memajukan kesejahteraan umum, mencerdaskan kehidupan bangsa dan ikut melaksanakan ketertiban dunia dengan berdasar kemerdekaan, perdamaian abadi dan keadilan sosial".

\section{Pemimpin berkewajiban untuk memelihara keutuhan dan kedaulatan negara}

Seorang kepala negara harus mampu menciptakan keamanan dan stabilitas nasional sehingga rakyatnya dapat beraktifitas dengan leluasa tanpa dihinggapi rasa ketakutan. Negara juga wajib melindungi negara dari serangan musuh sehingga keutuhan dan kedaulatan negara dapat terjaga. Untuk merealisasikan hal ini, negara wajib mempersiapkan armada militernya guna mencegah segala bentuk ancaman serta serangan musuh. Terkait dengan kewajiban menjaga keamanan dan kedaulatan, al-Qur'an memberikan isyarat dalam QS. Al-Anfal: 60:

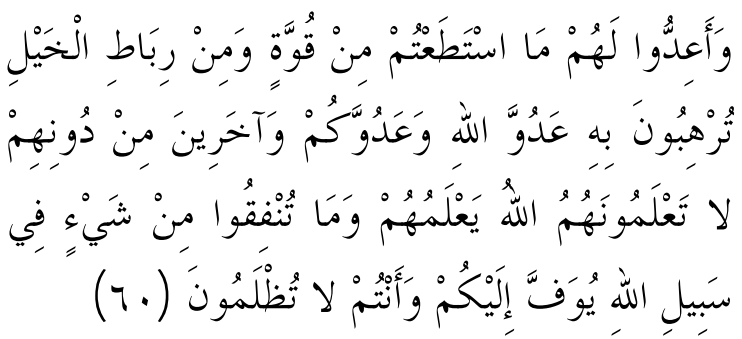


Dan siapkanlah untuk menghadapi mereka kekuatan apa saja yang kamu sanggupi dan dari kuda-kuda yang ditambat untuk berperang (yang dengan persiapan itu) kamu menggentarkan musuh Allah dan musuhmu dan orang orang selain mereka yang kamu tidak mengetahuinya; sedang Allah mengetahuinya. Apa saja yang kamu nafkahkan pada jalan Allah niscaya akan dibalasi dengan cukup kepadamu dan kamu tidak akan dianiaya (dirugikan). (QS. Al-Anfal [8]: 60).

Ayat di atas memberikan pesan bahwa kaum muslimin harus selalu dalam keadaan siap mempertahankan kedaulatannya dari serangan musuh dengan kekuatan dan kemampuan maksimal, sehingga dengan kekuatan tersebut maka musuh menjadi gentar. Dalam konteks keIndonesiaan, sebagaimana tercantum dalam Pembukaan UUD 1945, kepentingan nasional Indonesia adalah menjaga dan melindungi kedaulatan negara, keutuhan wilayah Negara Kesatuan Republik Indonesia, keselamatan dan kehormatan bangsa serta ikut secara aktif dalam usaha-usaha perdamaian dunia. Berangkat dari Pembukaan UUD 1945 di atas, maka kepentingan strategis pertahanan adalah menegakkan kedaulatan negara, mempertahankan keutuhan wilayah Negara Kesatuan Republik Indonesia (NKRI), dan keselamatan segenap bangsa dari ancaman militer serta ancaman bersenjata terhadap keutuhan bangsa dan negara.

TNI sebagai komponen utama dalam pertahanan negara memiliki tugas pokok menegakkan kedaulatan negara, mempertahankan keutuhan wilayah Negara Kesatuan Republik Indonesia (NKRI) berdasarkan Pancasila dan UndangUndang Dasar Republik Indonesia Tahun
1945, serta melindungi segenap bangsa dan seluruh tumpah darah Indonesia dari ancaman dan gangguan terhadap keutuhan bangsa dan negara. Menegakkan kedaulatan negara adalah mempertahankan kekuasaan negara untuk melaksanakan pemerintahan sendiri yang bebas dari ancaman. Tugas menjaga keutuhan wilayah NKRI adalah mempertahankan kesatuan wilayah kekuasaan negara dengan segala isinya. Sedangkan, melindungi segenap bangsa dan seluruh tumpah darah adalah melindungi jiwa, kemerdekaan dan harta benda setiap warga negara.

Selain mengatur kewajiban pemimpin, al-Qur'an juga mengisyaratkan kewajiban rakyat terhadap pemimpinnya, yaitu:

\section{a. Taat Kepada Pemimpin}

Sikap taat kepada aturan merupakan salah satu komitmen rakyat dalam relasinya dengan pemimpin. Dalam pandangan al-Qur'an, ketaatan kepada pemimpin merupakan salah satu indikasi iman, maknanya tidak ada iman tanpa ketaatan kepada pemimpin, sebagaimana dijelaskan dalam al-Qur'an:

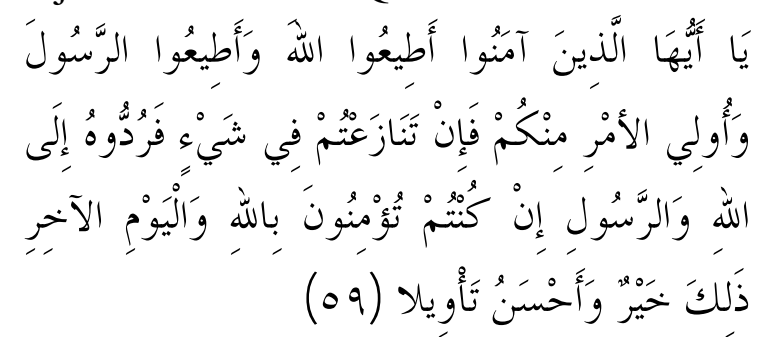

Hai orang-orang yang beriman, taatilah Allah dan taatilah Rasul (Nya), dan ulil amri di antara kamu, kemudian jika kamu berlainan pendapat tentang sesuatu, maka kembalikanlah ia kepada Allah (al-Quran) dan Rasul (sunnahnya), jika kamu benarbenar beriman kepada Allah dan hari kemudian, yang demikian itu lebih utama (bagimu) dan lebih baik akibatnya. (QS. An-Nisa [5]: 59) 
Ayat di atas menegaskan bahwa ketaatan dan iman tidak dapat dipisahkan. Dengan demikian, ketidaktaatan kepada pemimpin bukan saja dianggap salah dalam perspektif ilmu hukum, tetapi sekaligus menciderai keimanan. Oleh karenanya, setiap mukmin wajib mentaati aturan yang dibuat pemimpin selama peraturan tersebut tidak bertentangan dengan nila-nilai agama dan kesusilaan.

\section{b. Bertanggung jawab}

Dalam perspektif al-Qur' an manusia merupakan khalifah, termasuk rakyat. Sebagai khalifah, rakyat harus sadar bahwa di tangannyalah pengaturan alam raya ini diserahtugaskan guna dimanfaatkan demi kemaslahatan manusia dan alam raya. Dan amanah dari Tuhan tersebut tentunya harus dipertanggungjawabkan di hari akhir nanti, artinya segala sesuatu yang dilakukan ketika hidup di dunia akan dimintai pertanggujawabannya. Hanya saja, tanggung jawab di sini, bisa dibedakan dalam dua kategori, yakni tanggung jawab individu dan tanggung jawab sosial. Terkait dengan tanggung jawab individu, al-Qur'an menegaskan bahwa setiap manusia akan mendapatkan buku catatan amalnya, sebagaimana firman Allah:

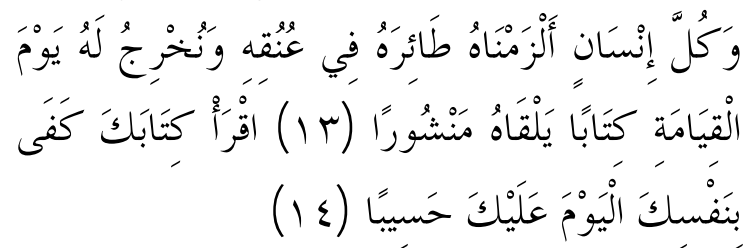

Dan tiap-tiap manusia itu telah Kami tetapkan amal perbuatannya (sebagaimana tetapnya kalung) pada lehernya, dan Kami keluarkan baginya pada hari kiamat sebuah kitab yang dijumpainya terbuka. "Bacalah kitabmu, cukuplah dirimu sendiri pada waktu ini sebagai penghisab terhadapmu". (QS. Al-Isra [17]: 13-14).
Sayyid Qutb memaknai ayat di atas merupakan kiasan tentang ketetapan amal setiap manusia, seolah amal perbuatannya itu menempel pada lehernya, untuk menggambarkan bahwa setiap amalnya akan tetap menyertai dirinya dan tidak akan terlepas dengannya. Begitupula ungkapan tentang dikeluarkannya kitab catatan amal dalam keadaan terbuka pada hari kiamat. Di sini Allah menggambarkan bahwa amal manusia itu akan terlihat jelas, dan ia tidak mampu untuk menyembunyikanya. ${ }^{13}$ Ayat ini juga merupakan peringatan kepada manusia agar selalu memperhitungkan dan memikirkan terlebih dahulu setiap tindakan dan keputusan yang diambil. Hal tersebut demi keselamatan dirinya. Sementara tanggung jawab sosial dapat dipahami dalam ayat sebagai berikut:

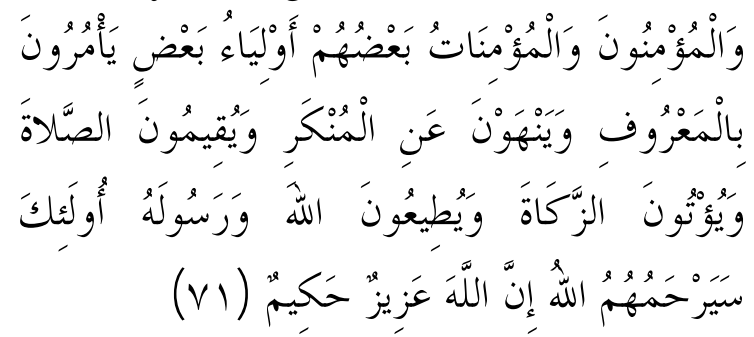

Dan orang-orang yang beriman, lelaki dan perempuan, sebahagian mereka (adalah) menjadi penolong bagi sebahagian yang lain. Mereka menyuruh (mengerjakan) yang ma'ruf, mencegah dari yang munkar, mendirikan shalat, menunaikan zakat dan mereka taat pada Allah dan Rasul-Nya, mereka itu akan diberi rahmat oleh Allah; Sesungguhnya Allah Maha Perkasa lagi Maha Bijaksana. (QS. At-Taubah [9]: 71)

Menurut ayat di atas, tanggung jawab sosial dapat berupa amar ma'ruf nahi munkar, menegakkan shalat, menunaikan zakat, serta mentaati Allah dan Rasul-Nya. Secara kontekstual ayat tersebut dapat

${ }^{13}$ Sayyid Quthb, Tafsir Fi Zhilalil Qur'an, Jakarta: Gema Insani Press, 2002, Hlm. 395. 
dipahami bahwa dalam struktur masyarakat, setiap muslim pasti memiliki perannya masing-masing. Oleh karena itu, dalam konteks tanggung jawab sama saja baik pemimpin maupun rakyat.

\section{c. Rakyat Berkontribusi Membela Negara}

Dalam al-Qur'an, ide dasar usaha bela negara adalah terciptanya rasa aman. Hal tersebut sebagaimana diisyaratkan dalam al-Qur'an:

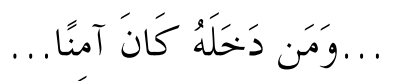

“...Barangsiapa memasukinya (Baitullah itu) menjadi amanlah dia...". (QS. Ali Imran [3]: 97)

Ayat di atas secara tersirat dapat dipahami sebagai dorongan kepada setiap warga di sebuah negara untuk secara sungguh-sungguh berupaya menciptakan rasa aman. Walaupun ayat di atas berbentuk kalimat berita, tetapi dapat dipahami sebagi perintah. Oleh karenanya, hal tersebut yang melandasi kewajiban bela negara. Kewajiban bela negara sudah dipraktekkan Rasullulah dalam perjalanan hidupnya. Hal tersebut dapat dilihat dari fakta sejarah ketika Rasulullah menginisiasi lahirnya Piagam Madinah. Dalam Piagam Madinah tersebut terdapat prinsip-prinsip pertahanan negara. Di antaranya pada pasal 37, 44, dan 24 yang menyatakan adanya "hak dan kewajiban umum" segenap rakyat Madinah dalam usaha mewujudkan pertahanan bersama dan bersama-sama mengeluarkan belanja perang selama mereka menghadapi perang bersama untuk mempertahankan keamanan kota Madinah. ${ }^{14}$ Berikut kutipan pasal yang terkait dengan pertahanan: ${ }^{15}$

${ }^{14}$ J. Suyuthi Pulungan, Prinsip-Prinsip Pemerintahan dalam Piagam Madinah Ditinjau dari Pandangan Al-Qur'an, Jakarta: PT. Raja Grafindo Persada, 1994, Hlm. 173.

${ }^{15}$ Ibnu Ishaq, Sirah Nabawiyah, Jakarta: Akbar Media Eka Sarana, 2016, Hlm. 301-304.
Pasal 37:

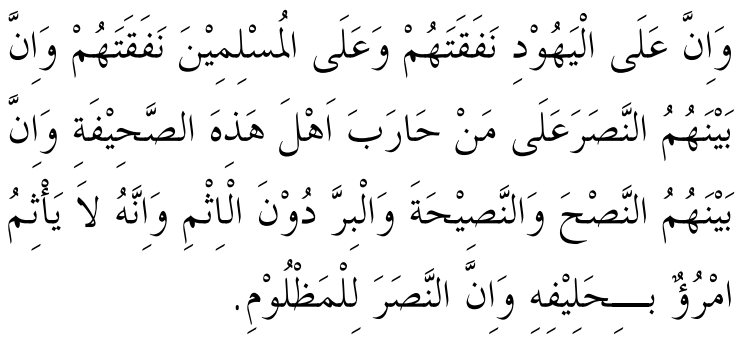

"Sesungguhnya kaum Yahudi wajib menanggung nafkah mereka dan orangorang mukmin wajib menanggung nafkah mereka sendiri. Tapi, di antara mereka harus ada kerja sama atau tolongmenolong dalam menghadapi orang yang menyerang warga shahifat ini, dan mereka saling member saran dan nasihat dan berbuat kebaikan, bukan perbuatan dosa. Sesungguhnya seseorang tidak ikut menanggung kesalahan sekutunya, dan pertolongan atau pembelaan diberikan kepada orang teraniaya".

Pasal 44:

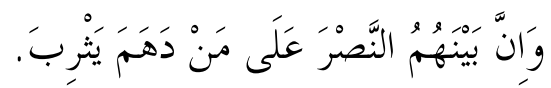

"Sesungguhnya di antara mereka harus ada kerjasama, tolong-menolong untuk menghadapi orang yang menyerang kota Yastrib".

Pasal 24:

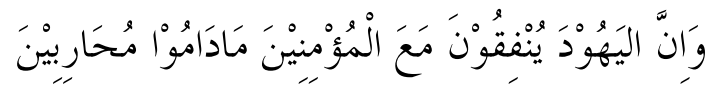

"Sesungguhnya kaum Yahudi bersamasama orang-orang mukmin berkerjasama dalam menanggung pembiayaan selama mereka mengadakan peperangan bersama".

Menurut penulis, ketiga pasal di atas terdapat isyarat bahwa sudah menjadi keharusan setiap warga negara yang tinggal di sebuah wilayah untuk menjaga kedaulatan dan keamanan negara dari segala bentuk ancaman musuh baik dari dalam maupun dari luar. Untuk mewujudkan negara yang aman, tentunya tidak dibebankan kepada satu pihak, melainkan tanggung jawab semua pihak, 
artinya setiap warga negara wajib berpartisipasi dalam mewujudkan kemaslahatan bersama. Perintah kerjasama dengan pihak lain (non muslim) dalam menjaga pertahanan sejalan dengan spirit dan ketententuan al-Qur'an:

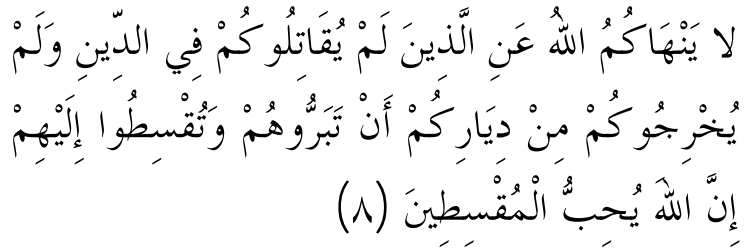

Allah tidak melarang kamu untuk berbuat baik dan berlaku adil terhadap orangorang yang tiada memerangimu karena agama dan tidak (pula) mengusir kamu dari negerimu. Sesungguhnya Allah menyukai orang-orang yang berlaku adil. (QS. Al-Mumtahanah [60]: 8).

Dalam konteks sekarang, bela negara dimaknai sebuah konsep yang disusun oleh perangkat perundangan dan petinggi suatu negara tentang patriotisme seseorang, suatu kelompok atau seluruh komponen dari suatu negara dalam kepentingan mempertahankan eksistensi negara tersebut. Secara fisik, hal ini dapat diartikan sebagai usaha pertahanan menghadapi serangan fisik atau agresi dari pihak yang mengancam keberadaan negara tersebut, sedangkan secara non-fisik konsep ini diartikan sebagai upaya untuk serta berperan aktif dalam memajukan bangsa dan negara, baik melalui pendidikan, moral, sosial maupun peningkatan kesejahteraan orang-orang yang menyusun bangsa tersebut.

Pemerintah Indonesia sesuai amanat dalam Pasal 30 ayat (1) UUD 1945 menyatakan bahwa "tiap-tiap warga negara berhak dan wajib ikut serta dalam usaha pertahanan dan keamanan negara" dan Pasal 9 UU Nomor 3 Tahun 2002 menyatakan bahwa "setiap warga negara berhak dan wajib ikut serta dalam upaya bela negara diwujudkan dalam penyelenggaraan pertahanan negara". Saat ini menjalankan program pelatihan bela negara yang terbuka bagi seluruh lapisan masyarakat. Program tersebut dimaksudkan untuk memperteguh keyakinan berdasarkan lima unsur yaitu cinta tanah air, kesadaran berbangsa \& bernegara, yakin akan Pancasila sebagai ideologi negara, rela berkorban untuk bangsa dan negara, serta memiliki kemampuan awal bela negara. Dan program ini bukanlah sebuah bentuk wajib militer.

\section{d. Berperan serta dalam pelaksanaan kebajikan}

Dalam sebuah negara telah ditetapkan peraturan-peraturan agar tercapainya kemaslahatan dan kebaikan bersama. Oleh karenanya sudah menjadi kewajiban bagi setiap warga negara untuk berpartisipasi melaksanakan peraturanperaturan tersebut. Rakyat harus saling mengingatkan untuk melaksanakan aturan yang benar dan berpihak pada rakyat. Hal tersebut sebagaimana diisyaratkan dalam al-Qur'an:

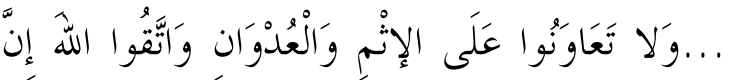

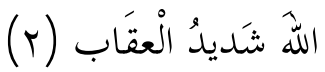

...dan tolong-menolonglah kamu dalam (mengerjakan) kebajikan dan takwa, dan jangan tolong-menolong dalam berbuat dosa dan pelanggaran. Dan bertakwalah kamu kepada Allah, sesungguhnya Allah amat berat siksa-Nya. (QS. Al-Maidah [5]: 2)

Ayat di atas dapat dimaknai bahwa tolong-menolong dalam kebaikan dan melaksanakan kebajikan merupakan kewajiban bagi rakyat. Oleh karena itu, 
sebagai konsekuensinya jika tidak melaksanakan kebajikan maka akan mendapatkan sanksi.

\section{Penutup}

Al-Qur'an sebagai petunjuk hidup membahas hubungan antara pemimpin dengan rakyat. Hubungan keduanya lahir akibat dari perjanjian atau kontrak sosial. Setelah rakyat sepakat memilih pemimpinnya, maka lahirlah kewajiban dan hak. Kewajiban pemimpin yang diisyaratkan dalam al-Qur'an yaitu menegakkan keadilan (QS. An-Nisa [4]: 58), melindungi hak asasi rakyat (QS. AlAn'am [6]: 151-152), dan menjaga keutuhan negara (QS. Al-Anfal [8]: 60). Al-Qur'an juga mengisyaratkan kewajiban rakyat kepada pemimpinnya, yaitu menaati pemimpin (QS. An-Nisa [5]: 59), membela negara (QS. Ali Imran [3]: 92), dan berperan serta dalam melaksanakan kebajikan (QS. Al-Maidah [5]: 2).

\section{DAFTAR PUSTAKA}

Achmad. "Konsep Hak-Hak Asasi Manusia Dalam Al-Qur'an". Disertasi. PPs UIN Syarif Hidayatullah Jakarta, 2003.

al-Farmawi, Abdul Hayy. Metode Tafsir Mudhu'i dan Cara Penerapannya, diterjemahkan oleh Rosihan Anwar dari judul al-Bidayah Fi Tafsir alMaudhu'i. Bandung: Pustaka Setia, 2002.

Amirudin, M Hasbi. "Konsep Negara Islam Menurut Fazrul Rahman". Disertasi. Pascasarjana UIN Syarif Hidayatullah Jakarta, 1999.

Dewan Redaksi Ensiklopedi Islam. Ensiklopedi Islam. Jakarta: PT. Ichtiar Baru Van Hoeve, 1997.
Hanafi, Hanafi M (ed), et al. Al-Qur'an dan Kenegaraan (Tafsir Al-Qur'an Tematik). Jakarta: Lajnah Pentashihan Mushaf Al-Qur'an, 2011.

Hukum, Keadilan, dan Hak Asasi Manusia (Tafsir Al-Qur'an Tematik). Jakarta: Lajnah Pentashihan Mushaf Al-Qur'an, 2010.

Ishaq, Ibnu. Sirah Nabawiyah. Jakarta: Akbar Media Eka Sarana, 2016.

Katsir, Ibnu. Tafsir Ibnu Katsir. Diterjemahkan oleh M. Abdul Ghoffar E.M dari judul Lubâbu atTafsîr Ibnu Katsîr, Jakarta: Pustaka Imam Syafi' i, 2004.

Kementrian Agama RI. Al-Qur'an dan Tafsirnya. Jakarta: Widya Cahaya, 2011.

Kresna, Aryaning Arya, dkk. Etika dan Tertib Hidup Berwarga Negara, Jakarta: Penerbit Salemba Humanika, 2010

al-Maududi, Abul A'la. Khilafah dan Kerajaan. Diterjemahkan oleh M. Al-Baqir dari judul al-Khilafah wa al-Mulk, Bandung: Penerbit Karisma, 2007.

al-Mawardi, Abu Al-Hasan Ali Ibn Muhammad Ibn Habib. Al-Ahkam As-Sultoniyah. Mesir: Darul Hadith, 2006.

Pulungan, J. Suyuti. Prinsip-Prinsip Pemerintahan Dalam Piagam Madinah Ditinjau Dari Pandangan Al-Qur'an. Jakarta: PT RajaGrafindo Persada, 1994.

Quthb, Sayyid. Tafsir Fi Zhilalil Qur'an. Jakarta: Gema Insani Press, 2002. 
Rosyada, Dede, et al. Pendidikan Kewargaan (Civic Education): Demokrasi, Hak Asasi Manusia dan Masyarakat Madani. Jakarta: Prenada Media, 2003.

Shobahussurur, "Islam dan Kekuasaan (Studi Analitik Tentang Kritik Ibn Taimiyah Terhadap Sistem Kekuasaan)". Disertasi. PPs UIN Syarif Hidayatullah Jakarta, 2005.
Tim Penyusun Kamus Pusat Pembinaan dan Pengembangan Bahasa Depdikbud RI. Kamus Besar Bahasa Indonesia. Jakarta: Balai Pustaka, 1988 